\title{
Morphology and Stem Anatomy of Chenopodium Species from Egyptian Flora
}

\author{
Ali Gaafar \\ Botany Department, Faculty of Science, New Valley University, El-kharga, Egypt.
}

\begin{abstract}
QTEM anatomy, stomatal types and stomatal index along with morphological characters of

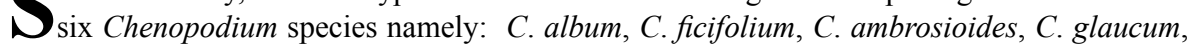
$C$. murale and $C$. quinoa were investigated by using light microscopy. Two types of stomata were recorded: Anisocytic type commonly recorded in five species, while anomocytic recorded only in C. ambrosioide. Leaf epidermal anatomy revealed great taxononmic value which can be used for the identification of species. Artificial key was provided for the identification of the studied species.
\end{abstract}

Keywords: Chenopodium, Light microscopy, Morphological characters, Stem anatomy, Stomatal morphology,

\section{Introduction}

Chenopodium, L. (family Chenopodiaceae) is a genus of annual to perennial herbaceous plants. It includes 150 species of worldwide distribution (Mabberley, 1989), most of them are annual, adapted to warm or mild-warm areas. The genus is divided into 16 sections according to Aellen (1960). In Egypt, Chenopodium species inhabited variety of habitats of different regions as a weed of cultivation and waste ground in Mediterranean Coast and Nile Delta; the genus is represented by 9 species and one variety in Egypt (Täckholm 1974; El-Hadidi \& Fayed, 1994/95 and Boulos, 1999). The genus Chenopodium has been subjected to many taxonomic studies; yet it is poorly understood and is widely considered to be a difficult genus (Carolin et al., 1978; Sukhorukov \& Zhang, 2013 and Sukhorukov \& Kushunina, 2014). Morphological and anatomical feature of Chenopodium has been studied by some authors (Artschwager, 1920; Malekloo et al., 2008, 2010 and Ahmad et al., 2010). This study aimed to characterize and resolve the extent of similarities and variations between the studied species of the genus Chenopodium using comparative analysis of morphology and anatomical characters of the stem.

\section{Materials and Method}

The collection of the botanical material and the field observations of the studied species were collected from different localities in New Valley (El-kharga) and Sharkia Governorate (DyarbNegm) (Table 1), authentic specimens were kept in Herbarium of Faculty of Science, Assiut University (New Valley Branch). Stem cross sections have been carried out using fresh materials which were fixed in ethanol $70 \%$ and carried out according to Johansen (1940); semi-permanent and permanent slides were prepared for studying under microscope. Sections were stained using safranin and light green combination and then mounted in Canada balsam (Sass, 1961). Stomata and stomatal index were carried out according to methods of Ahmad et al. (2010). Terminology followed (Prabhakar, 2004 and Metcalfe \& Chalk, 1950). The stomatal index (SI) was calculated using the formula described by Salisbury (1972) as follows:

$$
\mathrm{SI}=\mathrm{S} /(\mathrm{S}+\mathrm{E}) \times 100
$$

where $S$ donates the number of stomata per unit area and $E$ the number of epidermal cells in the same unit area.

\section{Results}

Macromorphological characters

Examined taxa were mostly annual; stem erect, angular in C. album rounded in the rest of the studied taxa, glabrescent; aromatic in C. ambrosioides, non aromatic in the rest studied taxa. Leaves aromatic in $C$. ambrosioides and non- aromatic in the rest

Corresponding author email: aligaafar2006@yahoo.com

DOI: 10.21608/ejbo.2018.4699.1193

Edited by: Prof. Dr. Monier M. Abd El-Ghani, Faculty of Science, Cairo University, Cairo, Egypt.

C2019 National Information and Documentation Center (NIDOC) 
studied taxa. rhombic, ovate to broadly lanceolate, cuneate at the base, irregular serrate of margin, apex acute to acuminate in C. album, oval acute to acuminate of apex, toothed margin C. ambrosioides, leave blade distinctly 3- lobed, narrowly ovate to elongate toothed or rarely entire of margin with pair of basal lobes, cuneate base, obtuse to sub-acute of apex in C. ficifolium. Blade triangular, ovate or rhombic ovate, base cuneate to rounded, margin irregularly dentate, apex acute to acuminate in $C$. murale, oblong ovate to lanceolate attenuate at the base, margin irregularly arose to dentate, apex acute or obtuse in C. glaucum and rombic to ovate broadly cuneate irregularly undulate serrate of margin, apex obtuse in C. quinoa. Inflorescence varied form large with axillary long spike in C. album, glomerulus in C. ambrosioides, lateral paniculate in C. ficifolium, terminal and lateral glomerules in C. quinoa, terminal axillary in C. murale and several per glomerules in spicate or paniculate in C. glacum. Perianth segments 3-4 in C. glucum, 3 in C. quinoa, 3-5 in C. ambrosioides and 5 in the rest taxa.

Pericarp free, easily detached in C. album, firmly adherent $C$. murale and $C$. ficifolium, loose and thin $C$. glaucum, while it was non adherent in the rest of the studied taxa.

\section{Micromorphological characters \\ Stomatal characters}

The types and stomatal number in addition to stomatal index seem to be important between the taxa (Table 2). Stomatal types and index observed in all the studied species of Chenopodium are illustrated in Plate I. Leaf epidermal cell margins varied from undulated in C. album and C. ficifolium, (Figs. 1 and 3) straight (in C. murale and C. quinoa (Figs. 5 and 6) or wavy in C. ambrosioides and C. glaucum (Figs. 2 and 4). Two types of stomata are recognized. anomocytic type was found only in C. ambrosioides (Plate I, Fig. 2) while, the anisocytic type were recorded in the rest of the studied taxa (Plate I).

TABLE 1. Species of Chenopodium used in this study and their sectional delimitation, indicate the place and date for each taxon.

\begin{tabular}{|c|c|c|c|c|}
\hline No. & Species & Collection & Subgenus & Section \\
\hline $1-$ & C. album $\mathrm{L}$. & $\begin{array}{c}\text { New Valley - El- } \\
\text { kharga,3.2016; A.Gaafar }\end{array}$ & Chenopodium & Chenopodium \\
\hline $2-$ & C. ambrosioides $\mathrm{L}$. & $\begin{array}{c}\text { Sharkia - Dyarb-Negm, } \\
\text { 3.2016; A.Gaafar }\end{array}$ & Ambrosia & Ambrina \\
\hline $3-$ & C. ficifolium Smith. & $\begin{array}{c}\text { Sharkia - Dyarb-Negm, } \\
\text { 3.2016; A.Gaafar }\end{array}$ & Chenopodium & Chenopodium \\
\hline $4-$ & C. glaucum $\mathrm{L}$. & $\begin{array}{c}\text { Sharkia - Dyarb-Negm, } \\
\text { 3.2016; A.Gaafar }\end{array}$ & Blitum & Agathophyton \\
\hline $5-$ & C. murale $\mathrm{L}$. & $\begin{array}{c}\text { New Valley - El- } \\
\text { kharga,3.2016; A.Gaafar }\end{array}$ & Chenopodium & Chenopodium sub sect. Undata \\
\hline $6-$ & ${ }^{*}$ C. quinoa Willd. & $\begin{array}{c}\text { New Valley - El- } \\
\text { kharga,3.2016; A.Gaafar }\end{array}$ & Chenopodium & Leprophyllum sub sect. cellulata \\
\hline
\end{tabular}

TABLE 2. Quantitative data of leaf epidermal cells of studied Chenopodium sp.

\begin{tabular}{|c|c|c|c|c|c|c|c|c|c|}
\hline \multirow[t]{2}{*}{ No. } & \multirow[t]{2}{*}{ Species } & \multirow{2}{*}{$\begin{array}{c}\text { Epidermal } \\
\text { type }\end{array}$} & \multicolumn{2}{|c|}{$\begin{array}{c}\text { No. of } \\
\text { epidermal cells }\end{array}$} & \multicolumn{2}{|c|}{$\begin{array}{c}\text { No. of } \\
\text { stomata }\end{array}$} & \multicolumn{2}{|c|}{$\begin{array}{l}\text { Stomatal } \\
\text { index }\end{array}$} & \multirow{2}{*}{$\begin{array}{c}\text { Stomatal } \\
\text { types }\end{array}$} \\
\hline & & & $\mathbf{A}$ & $\mathbf{L}$ & $\mathbf{A}$ & $\mathbf{L}$ & $\mathbf{A}$ & $\mathbf{L}$ & \\
\hline $1-$ & C. album & undulating & 72 & 65 & 14 & 20 & 16.28 & 23.53 & anisocytic \\
\hline $2-$ & C. ambrosioides & wavy & 55 & 40 & 10 & 15 & 15.38 & 27.27 & anomocytic \\
\hline $3-$ & C. ficifolium & undulating & 63 & 50 & 13 & 18 & 17.11 & 26.50 & anisocytic \\
\hline 4- & C. glaucum & wavy & 50 & 45 & 8 & 12 & 13.80 & 21.05 & anisocytic \\
\hline 5- & C. murale & straight & 60 & 45 & 14 & 22 & 18.91 & 32.83 & anisocytic \\
\hline $6-$ & C. quinoa & straight & 76 & 70 & 15 & 21 & 16.48 & 21.65 & anisocytic \\
\hline
\end{tabular}



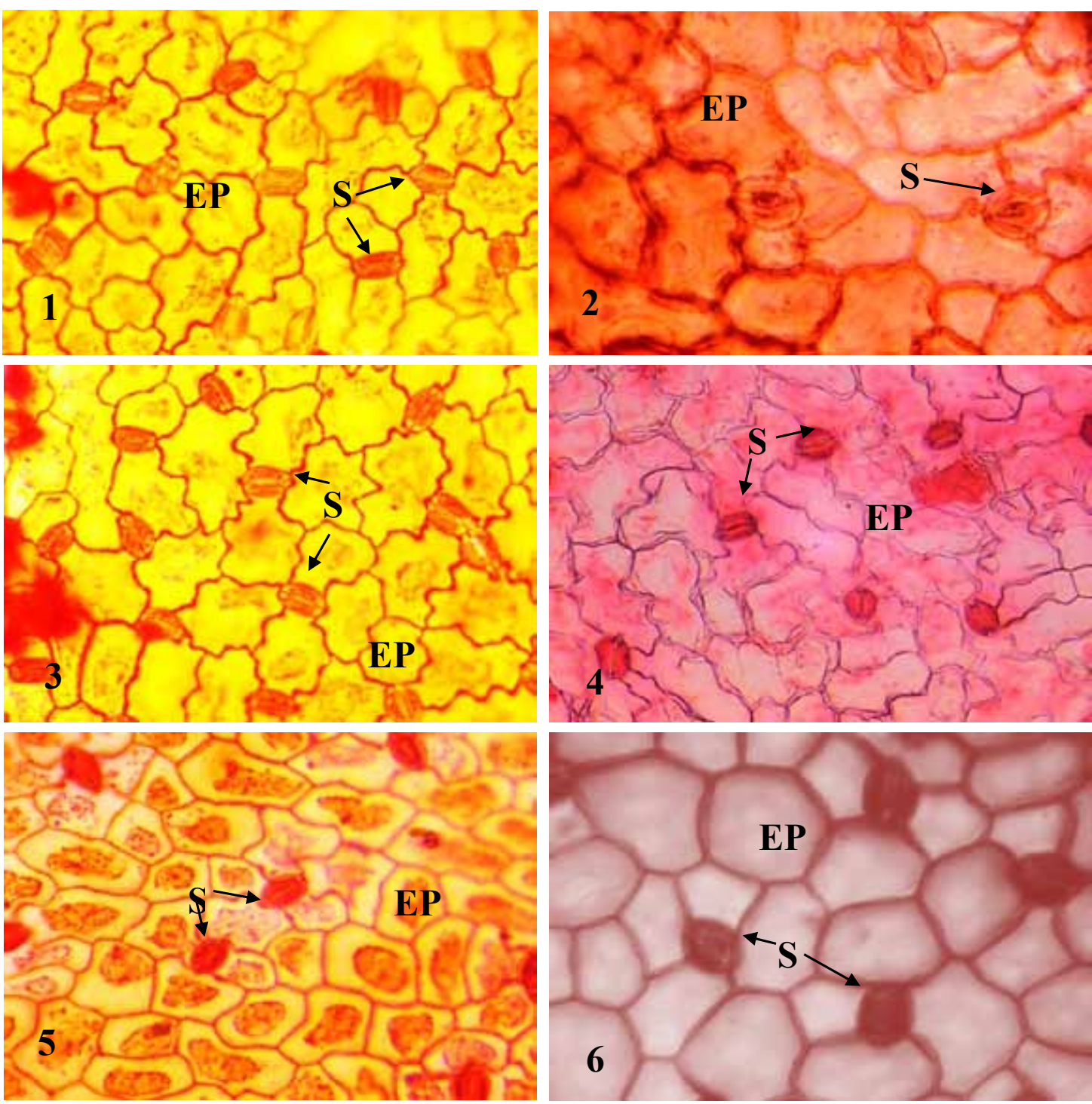

Plate I (Figs. 1-6). Leaf surface views of the studied species, 1: C. album, 2: C. ambrosioides, 3: C. ficifolium, 4: $C$. glaucum, 5: $C$. murale, 6: $C$. quinoa $[\mathrm{S}=\mathrm{Stomata}, \mathrm{EP}=$ Epidermal cell $]$.

\section{Stem anatomy}

Chenopodium album: Stem circular in outline, solid, outer cortical zone consists of papillose single layer of collenchymatous cells, outer cortical zone consists of 4-5 layers of angular collenchyma cells, in inner zone consists of 2-4 layers of parenchyma cells, Meristematic zone in the cortex in which the cambial ring outer of collateral vascular bundles. The medullary bundles are few and scattered gives patches of secondary xylem element alternating with patches of sclerified tissues. One ring of vascular rings and some of bundles moves inward to pith. Calcium oxalate (Druses) and sandy crystals are present in pith, stomata is anisocytic (Plate II, Fig. 1)

Chenopodium ambrosioides: Stem quadriangular in outline, solid, outer cortical zone consists of 5-7 layer of collenchymas cells, inner zone consists of 2-4 layers of parenchyma, the cambial ring of meristematic tissues gives patches of secondary xylem element alternating with patches of sclerified tissues which has sclerified parenchyma. Medullar bundles are numerous and arranged specially at the periphery of pith which represent narrow zone of polygonal parenchyma cells. Calcium oxalate (Druses) crystals are present in pith, stomata anomocytic (Plate II, Fig. 2). 

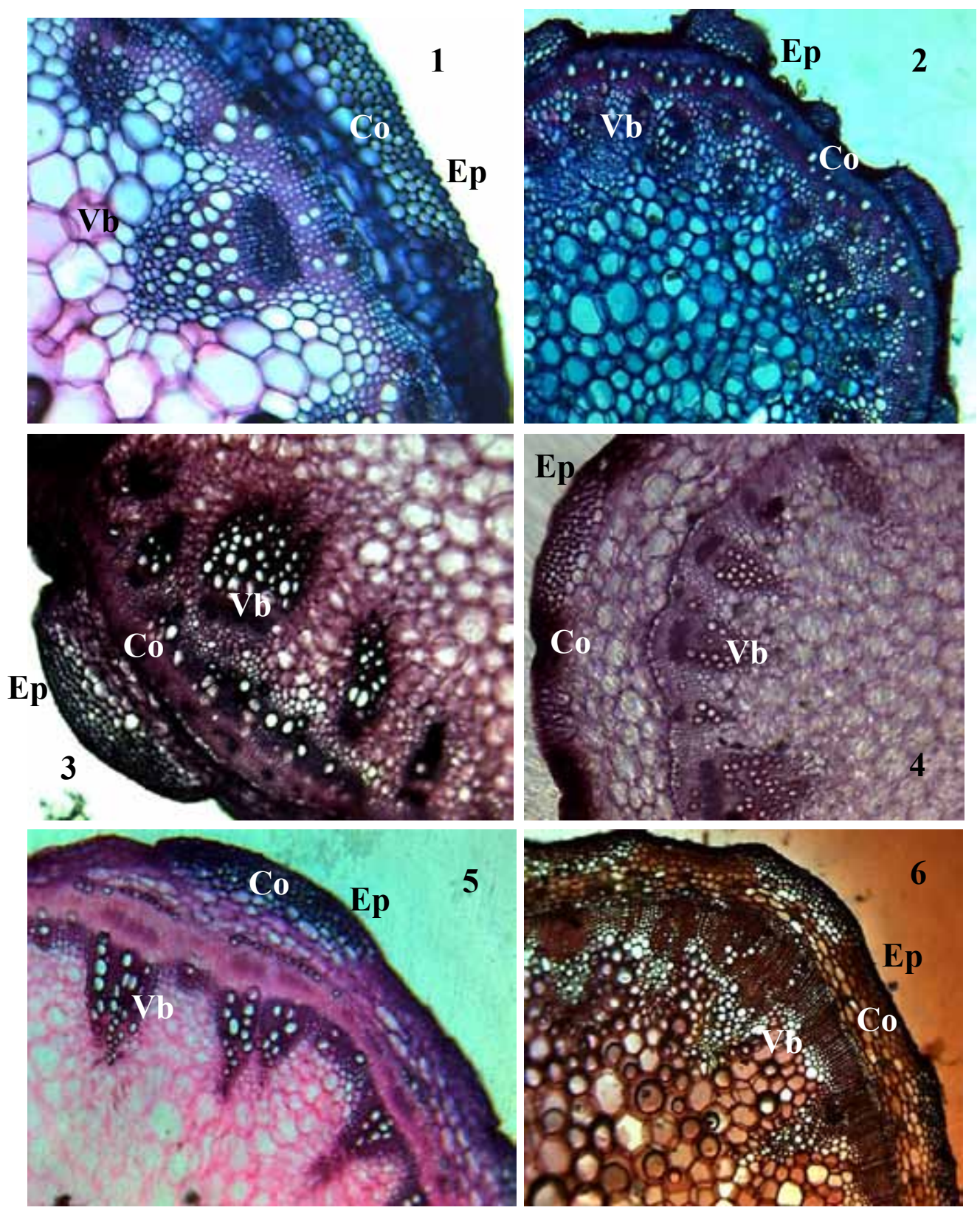

Plate II (Figs. 1-6). Photographs of the anatomical structure of stems of the studied species, 1: $C$. album, 2: $C$. ambrosioides, 3: $C$. ficifolium, 4: $C$. glaucum, 5: $C$. murale, 6: $C$. quinoa $[\mathrm{Ep}=$ Epidermal, $\mathrm{Vb}=$ Vascular bundle, $\mathbf{C o}=$ Cortex $]$.

Chenopodium ficifolium: Stem pentagonal in cross section, solid, epidermis has two layers of papillose shaped cells. Cortical zone consist of 4-6 layers of collenchymatous cells, scattered collateral primary vascular bundles separated by outer heterogeneous parenchyma cells and sclerifird parenchyma. Pith occupies a vast area containing numerous scattered medullar bundles. Sclerified homogenous parenchyma cells are present. A few Calcium oxalate (Druses) crystals are recorded in cortex and pith. Stomata anisocytic, surrounded by undulated subsidiary cells (Plate II, Fig. 3).

Chenopodium glaucum: Stem circular in cross section, solid, epidermis one layered of rounded cells. Outer Cortical zone consists of 5-8 layers of homogenous collenchymatous cells ended with patches meristematic tissues related by of 3-5 parenchymatous cells. No obvious medulla found; numerous collateral vascular bundles are scattered, some of them inward the meristematic tissues. Calcium oxalate (Druses) crystals are recorded in 
cortex and pith. Stomata anisocytic type, surrounded by sinuate subsidiary cells (Plate II, Fig. 4).

Chenopodium murale: Stem circular in cross section, solid, epidermis 1-2 layered of papillose elongated. The outer cortical zone consists of 4-5 layers of Angular collenchymatous cells. Continuous cambial ring is formed in the inner layers of the cortex surrounded the numerous vascular bundles. Some bundles move inwards to the pith zone. Druses crystals are recorded in cortex and pith. Stomata anisocytic (Plate II, Fig. 5).

Chenopodium quinoa: Pentagonal in cross section, solid, epidermis has two layers of papillose shaped cells. Cortical zone consist of 5-7 layers of collenchymatous cells, scattered collateral primary vascular bundles separated by outer heterogeneous parenchyma cells and sclerifird parenchyma. Pith occupies a vast area containing numerous scattered medullar bundles. Sclerified homogenous parenchyma cells are present. Druses crystals are recorded in cortex. Stomata anisocytic (Plate II, Fig. 6).

\section{Discussion}

Most of the investigated species showed distinct anatomical and morphological characters which can be used as a confirmatory taxonomic character (Malekloo et al., 2008; Ahmad et al., 2010 and Munir et al., 2011). In this work comparative anatomy is used in the investigated species of Chenopodium genus. According to Prabhakar (2004) and Metcalfe $\&$ Chalk (1950) anisocytic types of stomata were the most common in studied taxa while anomocytic type is found in C. ambrosioides. The stoma index of all the examined species shows a wide range of variation on upper and lower surfaces is presented in (Table 2). The epidermal cells were undulated in C. album and C. ficifolium, (section Chenopodium) and were wavy in C. ambrosioides (of section Ambrosia) and C. glaucum, (of section Blitum) while it was straight in $C$. murale and $C$. quinoa (section Chenopodium). Outline of the stem in cross section is generally circular, although in $C$. ficifolium, C. ambrosioides and C. quinoa it was angular (Plate II, Figs. 1-6). All the epidermal cells are papillose except in $C$. album. The cortex is generally distinguished into outer layer consists of collenchymas patches especially in ribs or parenchyma patches alternating to collenchymas. Inner layer consists of parenchyma which may be mixed with chlorenchyma. Primary vascular bundles are collateral conjoint and scattered in medulla arranged in ring. All stem of the investigated taxa are solid. Calcium oxalate crystals (Druses) are common in all the parenchyma of the studied species. These results are agree with finding of Metcalfe \& Chalk (1950). In old stem, most of the epidermal cells are replaced in older internode by tangentially elongated cells. Secondary growth starts with the initiation of a meristematic zone. In the outer cortex, there is a growth ring consisting of secondary xylem, move inwards and secondary phloem outwards. The conjunctive tissues consists of outer parenchyma and inner sclerified parenchyma.

A key is prepared based on morpho- anatomical characters for identification purposes as follows:

1. a. Leaves triangular, densely and sharply dentate; cortex with 1-2 layers of papillose shaped cells, 4-5 layers of angular collenchyma cells.

C. murale

1. b. Leaves distinctly 3- lobed, narrowly ovate; cortex with 2 layers of papillose shape cells, 4-6 layer of angular collenchyma cells .........................2

2. a. Inflorescence glomerules in terminal and lateral spikes ..................................................... ficifolium

2. b. Inflorescence terminal spikes ....................3

3. a. Aromatic; stomata anomocytic, cortex with 2-4 layers of parenchyma. Epidermis normal

C. ambrosioides

3. b. Non aromatic; sclerified homogenous parenchyma cells. epidermis papilliose ...................4

4 a. Leaves dentate C. quinoa

4. b. Leaves rhombic-ovate. .5

5. a. Leave up to $\leq 3-6 \mathrm{~cm}$ long, druses present in pith only, sand crystals present ...C. album

5. b. Leaves up to $\geq 1-2 \mathrm{~cm}$ long, druses present in cortex and pith, no sand crystals

C. glaucum

\section{Conclusion}

The morphological, anatomical of stem, epidermal cells and shape of stomata characters studied significant to the identification and taxonomy of the six species of Chenopodium measured in this study. The most reliable morphological and stem anatomical attributes have been used to build a dichotomous key for easy identification of each of the studied taxa. 


\section{References}

Aellen, P. (1960) Familie Chenopodiaceae.In: "Flora von Miteleeuropa", Illustrierte, Rechinger, K (Ed.) $2^{\text {nd }}$ ed., pp. 569-659. Carl Hansen Verlag, Munich, Germany.

Artschwager, F.E. (1920). On the anatomy of Chenopodium album L. American Journal of Botany, 7(6), 252-260.

Ahmad, K., Khan, M.A., Ahmad, M., Shaheen, N. and Nazir, A. (2010) Taxonomic diversity in epidermal cells of some sub-tropical plant species. International Jounal of Agriculture and Biology, 12(1), 115-118.

Boulos, L. (1999) "Flora of Egypt". Vol. 1. AzollaceaeOxalidaceae. Al Hadara Publishing, Cairo, Egypt. 94-98

Carolin, R.C., Jacobs, W.L. and Maret, V. (1978) Krnaz Cells and Mesophyll in the Chenopodiaceae. Aust. J. Bot. 26, 683-698.

El-Hadidi, N.M. and Fayed, A.A. (1994/95) Materials for Excursion Flora of Egypt (EFE), Taeckholmia, 15, 23

Johansen, D.A (1940) "Plant Microtechnique", pp. 126156. McGraw-Hill Book Co., New York.

Mabberley, D.J. (1989) "The Plant Book, a Portable Dictionary of the Higher Plants". Cambridge University Press, London. 706pp.

Malekloo, M., Hamdi, S.M.M., Assadi, M. and Nejadsatari, T. (2008) Micromorphological studies of the genus Chenopodium L. (Chenopodiaceae) in Iran. Biology Journal of Islamic Azad Univ. Garmsar Branch, 2(4), 39-50.

Malekloo, M., Hamdi, S.M.M., Assadi, M., and Nejadsatari, T. (2010) Morphological, micromorphological and anatomical studies of
Chenopodium album complex in Iran. Iran. J. Bot. 16(1), 69-75.

Metcalfe, C.R. and Chalk, L. (1950) "Anatomy of Dicotyledons". Vol.2. Clarendon press, Oxford.

Munir, M., Khan, A.M., Ahmad, M., Abbasi, M.A., Zafar, M., Khan, Y.K., Tariq, K., Tabassum, S., Ahmed, N.S., Ume Habiba and Bano, A. (2011)Taxonomic potential of foliar epidermal anatomy among the wild culinary vegetables of Pakistan. Journal of Medicinal Plants Research, 5(13), 2857-2862.

Prabhakar, M. (2004) Structure, delimitation, nomenclature and classification of stomata. Acta Botanica Sinica, 24(2), 242-252.

Salisbury, E.J. (1972) On the cause and ecological significance of stomatal frequency with special reference to the wood land flora. Philosophical transaction of royal society of London. Biol. Sci. 216, $1-65$.

Sass, J.E. (1961) "Botanical Microtechnique", $3^{\text {rd }}$ ed. Iowa State University Press, Ames, Iowa, USA, pp228.

Sukhorukov, A.P. and Zhang, M. (2013) Fruit and seed anatomy of Chenopodium and related genera (Chenopodioideae, Chenopodiaceae/ Amaranthaceae): Implications for evolution and taxonomy. PLoS ONE, 8(4), e61906. doi:10.1371/ journal.pone.0061906

Sukhorukov, A.P. and Kushunina, M. (2014) Taxonomic revision of Chenopodiaceae in Nepal. Phytotaxa, 191(1), 10-44.

Täckholm, V (1974) "Students' Flora of Egypt". $2^{\text {nd }}$ ed., Cairo University. pp888.

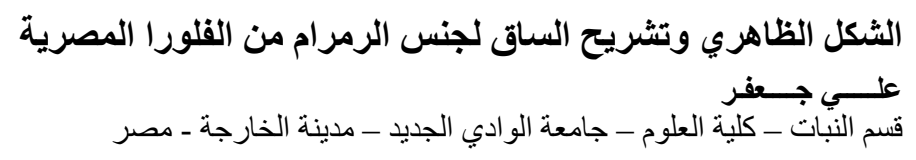

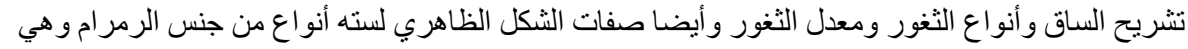

C. quinoa و C. album C. ficifolium C. ambrosioides ،C. glaucum ،C. murale

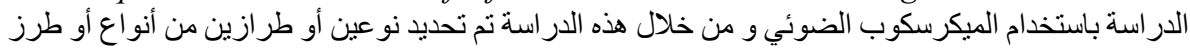

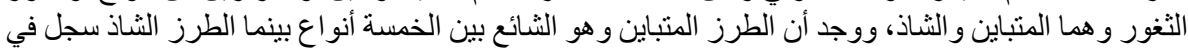

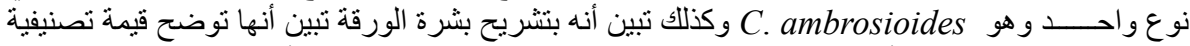

كبيرة تستخدم في تعريف الأنواع. ولقد تم عمل مفتاح اصطناعي لتحديد وتعريف الأنو اع المدروسة. 